\title{
Unit of Force
}

National Cancer Institute

\section{Source}

National Cancer Institute. Unit of Force. NCI Thesaurus. Code C69180.

An indication of the type of unit of measure being used to express the interaction between physical bodies. 